\title{
REVIEW
}

\section{Financial Inclusion in Nigeria: A Gender Gap Approach}

\author{
Wagbafor Marx O. ${ }^{1}$ Adenegan Kemisola O. ${ }^{1}$ Oladokun Yetunde O.M ${ }^{2^{*}}$ Olasehinde Toba ${ }^{3}$ \\ 1. Department of Agricultural Economics, University of Ibadan, Ibadan, Nigeria \\ 2. Economics and Extension Department, Cocoa Research Institute of Nigeria, Ibadan, Nigeria \\ 3. Institute of Agricultural Economics and Development, Graduate School of Chinese Academy of Agricultural \\ Sciences, Haidian District, Beijing, China
}

\section{ARTICLE INFO}

Article history

Received: 11 August 2021

Accepted: 31 August 2021

Published Online: 7 September 2021

\section{Keywords:}

Female

Male

Gender gap

Nigeria

\section{ABSTRACT}

Ability to have access and use financial goods and services such as bank and mobile money accounts indicates the overall financial inclusion level of an economy and the higher the indices are in any economy, the better that economy is. Financial inclusion is important to realize inclusive growth in any country. It has direct impacts on the level of growth and development experienced by any economy. It can however, be skewed along gender lines as noticed overtime in the Nigerian economy and other developing economies. This study examined financial inclusion in Nigeria: a gender gap approach. It also determined the factors responsible for the gender gaps. The Global Findex (2014) dataset of Nigeria from World Bank database was used to analyse the aims of the study. In the study, $61 \%$ of the men were financially included, while only $43 \%$ of the female were financially included, with $18 \%$ gap. The gap in endowments accounted for the huge difference of the gap in outcomes as males seemed to be more naturally favoured by society than females. The level of education, wealth quintile, saved in past 12 months for farm/business purposes, sent domestic remittances in the past 12 months, paid utility bills in the past 12 months, and received wage payments in the past 12 months are the factors explaining the gender gaps in Nigeria. Thus the government and other relevant stakeholders should encourage females along these factors.

\section{Introduction}

Financial inclusion is a critical factor for improving general well-being. Financial inclusion is a situation in which members of the society have right to use the banking and insurance companies as well as being learned financially. It could also be a condition where everyone has the right to proper financial products and services for effectual and competent organization of their capital; have access to desired capital to run their industries; and finan- cial power to take up prospects boosting their revenue.

${ }^{[1]}$ asserted that in this inclusive growth period, financial inclusion is a crucial means of improving people's welfare considerably thereby achieving national progress and prosperity.

Several studies have reported a gender gap in financial inclusion in developing countries ${ }^{[2-4]}$, with female-owned businesses facing more financial constraints than maleowned businesses. This gender gap is worrisome because exclusion of women from economic activities means that

\footnotetext{
*Corresponding Author:

Oladokun Yetunde O.M,

Economics and Extension Department, Cocoa Research Institute of Nigeria, Ibadan, Nigeria;

Email: yetunde.oladokun@gmail.com
} 
their important contribution to economic development will be minimal, underestimated or underutilized, if not totally absent. Furthermore, exclusion deprives women of their fundamental human rights which should allow them to have equal opportunity to participate in social and economic activities as the male gender. This study attempts to reveal this current gender gap in financial inclusion in Nigeria in details and suggest ways in which this gap can be narrowed down or totally closed up.

It is noteworthy that there exist many profit gotten from financial inclusion varying from small to big rewards ${ }^{[5-8]}$. The small rewards such as the capacity to begin and break even in businesses, long term asset in education, risk management and incorporation of financial shocks. Women are better than men when they have access to financial services because they spend more on food, education, and healthcare thus improving the livelihood and welfare of their people ${ }^{[9-11]}$. On a bigger scale the advantages are gainful employment, creating wealth, reducing income inequality, facilitating economic growth, improved savings and poverty reduction among the public. Improving women's rights to finance through formal financial services add to inclusive and healthy development of nations. As a result of these advantages, policy makers and financial regulators have put so much value on financial inclusion in their pursuit to attain a totally expanded financial sector ${ }^{[12,13]}$.

Nations such as Nigeria are possibly not wanting in good economic policies and strategy formulation; the trouble has always been on how the policies are put to use. As the decades have gone by, the number of people living in poverty continues to increase. There are therefore growing worries that the model of economic growth in Nigeria is distorted towards a few rich people, predominantly males, exempting the vast majority of the weaker persons in the public, whereas an economy cannot fully develop on a small percentage of its citizens while leaving the others ${ }^{[14]}$.

Whereas strategy execution, monitoring and evaluation is of great importance, little attention has been given to the concept of financial inclusion in terms of strategy formulation and actual policy implementation in Nigeria. There is a disturbing dearth in knowledge about the current state of financial inclusion in Nigeria. Existing studies on financial inclusion in Nigeria are very scanty and have neither revealed the current state of financial inclusion in Nigeria along gender lines, assessing the extent to which national initiatives and programs and strategies have attained their set targets. This study therefore assessed the current state of financial inclusion in Nigeria, particularly along gender lines and attempts to proffer suggestions to policymakers that would help in promoting national financial inclusion.

\section{Literature Review}

Several authors have come up with literature as a result of their findings while conducting research on financial inclusion globally and in different parts of the world. Most of the studies ${ }^{[15-17]}$ focused on secondary data which is available on Reserve Bank of India (RBI) data source to study the determinants and extent of financial inclusion.

Allen et al. (2012) examined whether greater account ownership and use of accounts are associated with affordable cost and greater proximity to financial intermediaries and discovered that lower-fee accounts, exempting depositors from documentation requirements, allowing correspondence banking and using bank accounts to receive government financial benefits are the special effective initiatives that promote financial inclusion among those likely to be excluded ${ }^{[18]}$.

Kohli (2013) investigated the factors which significantly impact financial inclusion and identified that there is a relationship between financial inclusion and levels of human development ${ }^{[19]}$. He found out those socio-economic factors. Income levels among individuals were found to have a significant influence on the level of financial inclusion. On the other hand, technology and education about the banking services were also found to be important factors that influence the growth of financial inclusion.

Efobi et al. (2014) explored the factors influencing the access to and use of banking services in Nigeria ${ }^{[20]}$. The results reveal that the individual attributes, income and ICT inclination are significant factors influencing the use of bank services in Nigeria.

The Central Bank of Nigeria has been at the fore front of encouraging and supporting financial products that are specifically targeted at the low income and financially excluded, while the government has focused more on both interventionist financing arrangements and building institutions and frameworks that promote financial inclusion. One of the critical initiatives in this direction was the incorporation of financial inclusion as one of the cardinal objectives of the Nigerian Financial System Strategy 2020. The Nigerian Financial System Strategy 2020 represents a holistic and strategic road map and framework for developing the Nigerian financial sector into a growth catalyst that will help Nigeria have one of the top 20 largest economies in the world by the year 2020 .

\section{Methodology}

The scope of this study is Nigeria. Secondary data from The Global Findex conducted in 2014 by Gallup Inc., in collaboration with the Nigerian Bureau of Statistics (NBS) was used in this study to reveal the financial 
inclusion status of one thousand households across the federation along gender lines. Nigeria is divided into thirty-six states and a Federal Capital Territory and sub-divided into 774 Local Government Areas (LGAs). The country is viewed as a multiethnic state as it is inhabited by 250 ethnic groups of which the three largest are the Hausa, Igbo and Yoruba; these ethnic groups speak over 250 different languages and are identified with a wide variety of cultures. The official language is however, English.

\subsection{Analytical Procedure}

Descriptive statistics was used to profile the socioeconomic characteristics of the respondent by gender and reveal the gender differential in access to financial inclusion among respondents while the Oaxaca-Blinder Decomposition method was used to decompose gender differentials into two components: a portion which arises because both male and female respondents on the average have the same treatment (equal right to use financial products and services) and a portion which arises because one group (in this case, males) is more favourably treated than the other (in this case, females) given the same individual characteristics (unexplained component). Mathematically, according to ${ }^{[21]}$, it can be shown as:

$\mathrm{Gap}=\mathrm{Q}+\mathrm{U}$

Where $\mathrm{Q}=$ explained component of the indicators of financial inclusion and $U=$ unexplained component of the indicators of financial inclusion.

Fortin et al. (2011) refer to this as the composition effect where $\mathrm{Q}$ is denoted as:

$Q=\left[E(X m)^{\prime}-E(X f)^{\prime}\right] \beta *$

The remaining part $(U)$ which is the "unexplained" part according to ${ }^{[22]}$ is due to the possibility of variables being omitted and thus creating biased estimates. It is attributed to discrimination (or differences in financial inclusion).

Fortin et al. (2011) also refer to this portion $(U)$ as the structure effect, which is equal to:

$U=(\alpha m-\alpha)+\left[E(X m)^{\prime}(\beta m-\beta *)\right]+(\alpha-\alpha f)+\left[E(X f)^{\prime}\right.$

$(\beta *-\beta f)]$

This equation can be subdivided into two distinct parts. One part quantifies the discrimination in favour of one group (or the structural advantage), in this case males as shown below:

$$
U m=(\alpha m-\alpha)+\left[E(X m)^{\prime}(\beta m-\beta *)\right]
$$

The other part, which quantifies the discrimination against (or the structural disadvantage) the other group, in this case females is as shown below:

$$
U f=(\alpha-\alpha f)+\left[E(X f)^{\prime}(\beta *-\beta f)\right]
$$

This method then discerns the portion of the gap which may be due to differences in characteristics, and the differences due to the structural effect. The structural effect permits the disaggregation of a possible advantage for males and a possible disadvantage for females. Thus, the method estimates a financial inclusion structure which is not obligatorily identical to that of either group ${ }^{[22]}$.

Lastly, we analyzed the determinants of financial inclusion in Nigeria using logistic regression (logit model). The model is as shown below:

$Y_{\mathrm{i}}=\beta \mathrm{X}_{1}+\mathrm{e}_{\mathrm{i}}$

$\operatorname{Prob}\left(Y_{\mathrm{i}}=1\right)=F\left(\beta^{\prime} \mathrm{X}_{\mathrm{i}}\right)$

$\operatorname{Prob}\left(Y_{\mathrm{i}}=0\right)=1-F\left(\beta^{\prime} \mathrm{X}_{\mathrm{i}}\right)$

Where: $Y_{\mathrm{i}}$ is the observed response for the $\mathrm{i}^{\text {th }}$ individual adult who is either financially included or not financially included. This means that $Y_{\mathrm{i}}=1$ for an individual adult who is financially included and $Y_{\mathrm{i}}=0$ for an individual adult who is financially excluded. $X_{i}$ is a set of independent variables such as age, sex and level of education among others, associated with the $i^{\text {th }}$ individual, which determine the probability of financial inclusion $(\mathrm{P})$. The function, F may take the form of a normal, logistic or probability function. The logit model uses a logistic cumulative distributive function to estimate, $\mathrm{P}$ as follows ${ }^{[23]}$ :

$\operatorname{Prob}\left(Y_{\mathrm{i}}=1\right)=\left[\frac{e^{\beta^{\prime} \mathrm{X}}}{1+{ }_{e} \beta^{\prime} \mathrm{X}}\right]$

$\operatorname{Prob}\left(Y_{\mathrm{i}}=0\right)=1-\left[\frac{e^{\beta^{\prime} \mathrm{X}}}{1+e_{\theta}^{\beta^{\prime} \mathrm{X}}}\right]_{=}\left[\frac{1}{1+e_{\theta}^{\beta^{\prime} \mathrm{X}}}\right]$

According to ${ }^{[24]}$, the probability model is a regression of the conditional expectation of $\mathrm{Y}$ on $\mathrm{X}$ giving:

$E(Y / X)=1\left[F\left(\beta^{\prime} \mathrm{X}\right)\right]+0\left[1-F\left(\beta^{\prime} \mathrm{X}\right)\right]=F\left(\beta^{\prime} \mathrm{X}\right) *$

Since the model is non-linear, the parameters are not necessarily the marginal effects of the various independent variables. The relative effect of each of the independent variables on the probability of financial inclusion by every person across Nigeria is obtained by differentiating equation (11) with respect to $X_{i j}$ and this results in equation (12) ${ }^{[24]}$ :

$\frac{\partial P_{i}}{\partial X_{i j}}=\left[\frac{{ }_{\alpha^{\prime}} \beta^{\prime} X}{\left(1+{ }_{{ }^{\prime} \beta^{\prime} X}\right)}\right] \beta=\mathrm{F}\left(\beta^{\prime} \mathrm{X}\right)\left[1-F\left(\beta^{\prime} \mathrm{X}\right)\right] \beta$

The maximum likelihood method was used to estimate the parameters. This estimation procedure resolves the problem of heteroscedasticity associated with other estimation procedures such as the Linear Probability Model (LPM). It constrains the conditional probability of inclusion of individual adults in the formal financial market to lie between zero (0) and one (1). The empirical model for the logit estimation is specified as follows: 
$\log \frac{P_{t}}{1-P_{t}}=\alpha+\beta \mathrm{X}_{\mathrm{i}}+\mathrm{e}_{\mathrm{i}}$

Where:

$\log \frac{P_{t}}{1-P_{t}}=$ the log-odds in favour of inclusion in the formal financial market;

$X_{\mathrm{i}}=$ the combined effects of $\mathrm{X}$ explanatory variables that determine or otherwise the financial inclusion of individual adults and ranges from $X_{1}$ to $X_{13}$ defined as follows: $\mathrm{q} 1=\mathrm{X} 1=\operatorname{Sex}$ (Dummy: $1=$ Male; $0=$ Otherwise) $\mathrm{q} 2=\mathrm{X} 2=$ Age of the individual adult (Years) q3 = X3 = Educational status (Dummy: $1=$ Literate; 0 $=$ Otherwise)

inc_q $=$ income quintile

q16 = made payments online using the internet

$\mathrm{q} 17 \mathrm{a}=$ saved in past 12 months for farm/business purposes

q26 $=$ sent domestic remittances in the past 12 months

q28 = received domestic remittances in the past 12 months

q30 $=$ paid utility bills in the past 12 months

q32 = paid school fees in past 12 months

q34 = received wage payments in the past 12 months

q39 = received government transfers in the past 12 months

$\mathrm{q} 43=$ received agricultural transfers in the past 12 months

\section{Results and Discussion}

\subsection{Socio-economic Characteristics of Respondents}

Table 1 presents the distribution of respondents according to their gender. The table revealed that 55.6 percent of the respondents were male while 44.4 percent were female. Table 2 presents the distribution of respondents according to their age. It reveals that 57.77 percent of the respondents were 30 years and below and 35.90 percent were between 31 and 60 years old. It could be inferred from here that Nigeria's population are predominantly youth. Furthermore, table 3 reveals that $32.88 \%$ of female respondents completed primary school, 63.96\% completed secondary school while only $3.15 \%$ completed tertiary education. Among the male respondents, 19.09\% completed primary education while $74.41 \%$ completed secondary and $6.49 \%$ completed tertiary education. This reveals that males are generally more educated than females in Nigeria. In total, only $5 \%$ of the respondents have completed tertiary education; this reveals a very poor literacy rate in Nigeria.

\subsection{Gender Differential in Access to Financial Inclusion}

Table 4 presents a summary of respondents with regards to their account ownership with a financial institution. It reveals that $62 \%$ of male respondents have accounts with a financial institution while $44 \%$ of female respondents have accounts with financial institutions and in total, $54 \%$ of respondents have accounts with financial

Table 1. Distribution of respondents by gender

\begin{tabular}{ccc}
\hline Gender & Frequency & Percentage \\
\hline Male & 555 & 55.6 \\
Female & 444 & 44.4 \\
Total & 999 & 100.00 \\
\hline
\end{tabular}

Source: Findex, 2014

Table 2. Distribution of respondents by age

\begin{tabular}{|c|c|c|c|c|c|c|}
\hline \multirow[t]{2}{*}{ Age (yrs.) } & \multicolumn{3}{|c|}{ Male } & \multicolumn{2}{|l|}{ Female } & \multirow{2}{*}{$\begin{array}{c}\text { All } \\
\text { Percentage }\end{array}$} \\
\hline & Frequency & Percentage & Freq. & Percentage & Freq. & \\
\hline 30 and below & 309 & 55.67 & 267 & 60.41 & 576 & 57.77 \\
\hline $31-60$ & 209 & 37.65 & 149 & 33.71 & 358 & 35.90 \\
\hline 61 and above & 37 & 6.67 & 26 & 5.88 & 63 & 6.32 \\
\hline $\begin{array}{l}\text { Total } \\
\text { Mean }\end{array}$ & 555 & 100.00 & 442 & 100.00 & 997 & $\begin{array}{c}100.00 \\
33.35707\end{array}$ \\
\hline Std. Dev. & & & & & & 14.09773 \\
\hline
\end{tabular}

Source: Findex, 2014

Table 3. Distribution of respondents by educational level

\begin{tabular}{|c|c|c|c|c|c|c|}
\hline & & Female & & Male & & Total \\
\hline & Frequency & Percentage & Frequency & Percentage & Frequency & Percentage \\
\hline Primary & 146 & 32.88 & 106 & 19.09 & 252 & 25.23 \\
\hline Secondary & 284 & 63.96 & 413 & 74.41 & 697 & 69.77 \\
\hline Tertiary & 14 & 3.15 & 36 & 6.49 & 50 & 5.01 \\
\hline Total & 444 & 100.00 & 555 & 100.00 & 999 & 100.00 \\
\hline Mean & & & & & & .7977978 \\
\hline Std. Dev. & & & & & & .5115452 \\
\hline
\end{tabular}

Source: Findex, 2014 
institutions. This also reveals that men are generally financially included than women and slightly above half of the total respondents are financially included in the area of account ownership with financial institutions.

Table 5 further presents a summary of respondents with regards to their mobile money account ownership information. It reveals that $3.1 \%$ of male respondents have mobile money accounts while $2.944 \%$ of female respondents have mobile money accounts. This reveals that men are generally financially included than women.

\subsection{Explaining Gender Differential in Financial Inclusion in Nigeria}

Table 6 reports the mean values of decomposition generated, of owning an account with a financial institution for the two groups (male and female), and the difference between them. It reveals that the financial inclusion $\mathrm{z}$ values among the male $(0.618)$ is higher than that of the females $(0.434)$ with a gap of 0.184 . It then goes further to show the contribution attributable to the gaps in endowments (E) at 0.095, the coefficients (C) at 0.092, and the interaction (CE) at -0.003 . The results reveal that the gap in endowments accounts for the great bulk of the gap in outcomes. Males seem to be more naturally favoured by society than females, and this perception makes it easier for a male to be financially included than a female. This result supports that of ${ }^{[25]}$ which highlighted some of the natural endowments enjoyed by the male gender to include better financial capability and literacy, better asset ownership level/ base for use as collateral, easier mobility, lesser play of discriminatory laws on males amongst others. As further revealed from table 7, the coefficient of group one (males) is seen to be 0.616 while that of the female group (2) is seen to be 0.434 with a difference of 0.182 observed between the two groups and a coefficient of 0.092 is observed for the explained part and 0.091 for the unexplained part of the decomposition. Is also reveals and compares the individual explained and unexplained coefficients.

\subsection{Determinants of Financial Inclusion in Nigeria}

The results of the logistic revealed a strong negative relationship between being a female and owning an account in a financial institution which indicates that a female is less likely to be financially included in the society at large. The coefficient indicates that being a female makes a person $47 \%$ less likely to be financially included. This finding supports the earlier assertions of ${ }^{[26]}$ and the earlier published ${ }^{[27]}$ reports on gender and financial inclusion. Furthermore, the results reveal that there is also a negative relationship between the income quintile to which an individual belongs and the rate of financial inclusion, hence, people of all quintiles are less likely to own an account in a financial institution, no matter the quintile to

Table 4. Distribution of respondents by account ownership with a financial institution

\begin{tabular}{|c|c|c|c|c|c|}
\hline Gender & Frequency & $\begin{array}{l}\text { count with a } \\
\text { es } \\
\text { Percentage }\end{array}$ & $\begin{array}{l}\text { itution? } \\
\text { Frequency }\end{array}$ & $\begin{array}{l}\text { No } \\
\text { Percentage }\end{array}$ & Total \\
\hline Male & 343 & 63.99 & 212 & 45.79 & 555 \\
\hline Female & 193 & 36.01 & 251 & 54.21 & 444 \\
\hline Total & 536 & 100 & 463 & 100 & 999 \\
\hline
\end{tabular}

Source: Findex, 2014

Table 5. Distribution of respondents by mobile money account ownership

\begin{tabular}{|c|c|c|c|c|c|}
\hline \multirow[b]{3}{*}{ Gender } & \multicolumn{4}{|c|}{ Has a mobile money account? } & \multirow{3}{*}{ Total } \\
\hline & & Yes & & \multirow{2}{*}{$\begin{array}{l}\text { No } \\
\text { Percentage }\end{array}$} & \\
\hline & Frequency & Percentage & Frequency & & \\
\hline Male & 17 & 56.67 & 538 & 55.52 & 555 \\
\hline Total & 30 & 100 & 969 & 100 & 999 \\
\hline
\end{tabular}

Source: Findex, 2014

Summary of decomposition results:

High: female $==$ male; $\quad$ Low: female $==$ female

Table 6. Mean values of decomposition generated

\begin{tabular}{lll}
\hline & Mean prediction high $(\mathrm{H}):$ & 0.618 \\
& Mean prediction low $(\mathrm{L}):$ & 0.434 \\
& Raw differential $(\mathrm{R})\{\mathrm{H}-\mathrm{L}\}:$ & 0.184 \\
& - due to endowments $(\mathrm{E}):$ & 0.095 \\
& - due to coefficients $(\mathrm{C}):$ & 0.092 \\
\hline
\end{tabular}

Source: Findex, 2014 
Macro Management \& Public Policies | Volume 03 | Issue 03 | September 2021

Table 7. Coefficient estimates, means, and predictions for each of the factors that influence the rate of financial inclusion

\begin{tabular}{|c|c|c|c|c|c|c|}
\hline account_fin & Coefficient & $\begin{array}{c}\text { Robust } \\
\text { Standard Error }\end{array}$ & Z & $\mathrm{P}>|\mathrm{z}|$ & \multicolumn{2}{|c|}{ [95\% Conf. Interval] } \\
\hline \multicolumn{7}{|l|}{ Overall } \\
\hline group_1 & .6159376 & .0208258 & 29.58 & 0.000 & .5751197 & .6567555 \\
\hline group_2 & .4340655 & .0230509 & 18.83 & 0.000 & .3888866 & .4792444 \\
\hline Difference & .1818721 & .0310654 & 5.85 & 0.000 & .120985 & .2427591 \\
\hline Explained & .0995736 & .0170636 & 5.84 & 0.000 & .0661296 & .1330176 \\
\hline unexplained & .0822985 & .0282471 & 2.91 & 0.004 & .0269351 & .1376618 \\
\hline Age & .0029616 & .0023662 & 1.25 & 0.211 & -.0016761 & .0075993 \\
\hline Educ & .0382878 & .0088723 & 4.32 & $0.000 *$ & .0208983 & .0556772 \\
\hline inc_q & .0112818 & .0044261 & 2.55 & $0.011 * *$ & .0026068 & .0199568 \\
\hline Saved & .0130785 & .0053033 & 2.47 & $0.014 * *$ & .0026842 & .0234728 \\
\hline Sent DM & .009174 & .0045369 & 2.02 & $0.043 * *$ & .0002818 & .0180661 \\
\hline Rec DM & .0013027 & .0037024 & 0.35 & 0.725 & -.0059539 & .0085592 \\
\hline Util B & .0178357 & .0061223 & 2.91 & $0.004 *$ & .0058362 & .0298352 \\
\hline Wage P & .0066621 & .0039832 & 1.67 & $0.094 * * *$ & -.0011447 & .014469 \\
\hline Govt trf & -.0014968 & .0020591 & -0.73 & 0.467 & -.0055326 & .002539 \\
\hline Agric Trf & -.0013909 & .0022932 & -0.61 & 0.544 & -.0058854 & .0031037 \\
\hline \multicolumn{7}{|l|}{ Unexplained } \\
\hline Age & .0912407 & .0628079 & 1.45 & 0.146 & -.0318604 & .2143419 \\
\hline Educ & .03495 & .0448693 & 0.78 & 0.436 & -.0529923 & .1228922 \\
\hline inc_q & -.0364762 & .0298849 & -1.22 & 0.222 & -.0950495 & .022097 \\
\hline Saved & -.0279635 & .0181135 & -1.54 & 0.123 & -.0634653 & .0075382 \\
\hline Sent DM & .0317977 & .0268169 & 1.19 & 0.236 & -.0207626 & .0843579 \\
\hline Rec DM & .0128508 & .0308248 & 0.42 & 0.677 & -.0475646 & .0732663 \\
\hline Util B & -.0039961 & .0212185 & -0.19 & 0.851 & -.0455836 & .0375913 \\
\hline Sch Fees & .018303 & .0160893 & 1.14 & 0.255 & -.0132315 & .0498374 \\
\hline Wage P & -.0150001 & .0163945 & -0.91 & 0.360 & -.0471327 & .0171326 \\
\hline Govt Trf & .0146193 & .0105411 & 1.39 & 0.165 & -.0060409 & .0352795 \\
\hline Agric Trf & .0256995 & .017216 & 1.49 & 0.135 & -.0080433 & .0594423 \\
\hline \multirow[t]{5}{*}{ _cons } & -.0637265 & .0983316 & -0.65 & 0.517 & -.2564529 & .1289998 \\
\hline & $\mathrm{N}$ of obs 2 & \multicolumn{5}{|c|}{442} \\
\hline & Model & \multicolumn{5}{|c|}{ Probit } \\
\hline & Group 1 & \multicolumn{5}{|c|}{ female $=0$} \\
\hline & Group 2 & \multicolumn{5}{|c|}{ female $=1$} \\
\hline
\end{tabular}

* Significant at $99 \%, \quad * *$ Significant at $95 \% \quad * * *$ Significant at $90 \%$

Source: Findex, 2014

Table 8. Logistic regression results

\begin{tabular}{ccccccc}
\hline account_fin & Coef. & Std. Err. & $\mathrm{Z}$ & $\mathrm{P}>|\mathrm{z}|$ & \multicolumn{2}{c}{$[95 \%$ Conf. Interval] } \\
\hline Female & -.4796217 & .1526358 & -3.14 & $0.002^{*}$ & -.7787824 & -.1804611 \\
Age & .0111193 & .0056548 & 1.97 & $0.049^{* *}$ & .0000361 & .0222025 \\
Educ & 1.208653 & .1758274 & 6.87 & $0.000^{*}$ & .8640374 & 1.553268 \\
inc_q & -.1854936 & .0526705 & -3.52 & $0.000^{*}$ & -.288726 & -.0822613 \\
Internet P & .2092496 & .2121826 & 0.99 & 0.324 & -.2066206 & .6251198 \\
Sent DM & .593079 & .1409989 & 4.21 & $0.000^{*}$ & .3167262 & .8694318 \\
Rec DM & .5615653 & .1426196 & 3.94 & $0.000^{*}$ & .2820361 & .8410946 \\
Util B & .7263235 & .1349345 & 5.38 & $0.000^{*}$ & .4618567 & .9907903 \\
Sch Fees & .2297873 & .1350348 & 1.70 & $0.089^{* * *}$ & -.034876 & .4944505 \\
Wage P & .488423 & .1636377 & 2.98 & $0.003^{*}$ & .1676989 & .809147 \\
Govt Trf & -.1215348 & .2100707 & -0.58 & 0.563 & -.5332658 & .2901962 \\
Agric Trf & -.1494187 & .1168706 & -1.28 & 0.201 & -.3784809 & .0796435 \\
cons & -1.672945 & .3160041 & -5.29 & $0.000^{*}$ & -2.292302 & -1.053588 \\
& Number of obs & & & & 997 & 310.80 \\
\\
LR chi ${ }^{2}(12)$ & & & & & 0.0000 & -532.99189 \\
\end{tabular}

* Significant at $99 \%, \quad * *$ Significant at $95 \%$

$* * *$ Significant at $90 \%$

Source: Author's Computation MICS (2016/2017) 
which they belong. We also find negative relationships between receiving government and agricultural transfers in the past 12 months and owning an account in a financial institution. This also reveals that generally, people who have family members and trusted persons who are already financially included do not mind receiving government and agricultural transfers through such people if need be. The results show that gender (being a female), age, educational qualification attained, the income quintile to which an individual belongs, sending and receiving domestic remittances (especially in the past 12 months), utility bills payment, school fees payment and reception of wage payments (especially in the past 12 months) are all significant factors that affect the rate of financial inclusion in Nigeria. Age, education, sending domestic remittances in the past 12 months, receiving domestic remittances in the past 12 months, paying utility bills in the past 12 months, paying school fees in past 12 months and receiving wage payments in the past 12 months were significant and showed positive relationships with owning an account in a financial institution or being financially included. The results indicate that people are more likely to be financially included as they grow older (by $1 \%$ ), get more educated (by $120 \%$, which indicates total certainty), send domestic remittances (by 59\%), received domestic remittances (by $56 \%$ ) pay utility bills (by $72 \%$ ), pay school fees (by $23 \%$ ) and receive wage payments (by $48 \%$ ).

Out of all the significant determinants of financial inclusion, educational qualification seems to have the greatest certainty which implies that the most certain way to get people financially included is to get them more educated. This explains why the older generation with lesser educational attainment seems to be more comfortable engaging in cash transactions compared to the younger generation who are generally more educated and less likely to engage in cash transactions.

\section{Summary of Major Findings}

Fifty eight percent of the respondents were 30 years and below and $35.90 \%$ were between 31 and 60 years old, inferring that the younger generation are generally more financially included than the older generation. With only $5 \%$ of the respondents shown to have completed tertiary education, males were revealed to be generally more educated than females in Nigeria with $74.41 \%$ seen to have completed secondary education as against their female counterparts who showed $63.96 \%$; and $6.49 \%$ males found to have completed tertiary education as against $3.15 \%$ in females. Also, the 5th (richest) quintile had the highest number of respondents compared to the others and men were found to earn more income than women in Nigeria. The results further revealed that $62 \%$ of male respondents have accounts while $44 \%$ of female respondents have accounts and in total, $54 \%$ of respondents have accounts thus revealing that men are generally financially included than women and slightly above half of the total respondents are financially included, owning accounts (with a financial institution).

Furthermore, the differences in the effects of the determinants of financial inclusion play a minimal role in explaining the gender gap in financial inclusion in Nigeria. Also, the only gaps that favoured the females were received government transfers in the past 12 months and received agricultural transfers in the past 12 months whereas the gaps in the remaining variables all disfavoured the females. The gap in educational qualification, however accounted for the bulk of the explained gap.

The logistic regression results revealed a strong negative relationship between being a female and owning an account in a financial institution thereby indicating that a female is less likely to be financially included in the society at large. Educational qualification had the greatest certainty of all the significant determinants of financial inclusion, implying therefore that the most certain way to get people financially included is to get them more educated.

\section{Conclusions and Recommendations}

The study concluded that there is a significant gap in financial inclusion in Nigeria along gender lines, with males being more financially included than females. Among all the determinants of financial inclusion, education played the most crucial role from the results gotten. The study therefore recommends that the Nigerian government should intensify efforts to drive financial inclusion, giving special consideration to females. Government should look more closely into creating equal opportunities for males and females during socioeconomic planning and give women equal access to assets, training, education and other human capital development activities. This would address the gap in endowments between females and their male counterparts considerably. Financial institutions should come up with incentives and strategies that encourage females to own and use accounts with financial institutions such as special training, grants, loans, lesser interest rates among others. Such developments will encourage females to own and use accounts with financial institutions. Government should look closely into policies and frameworks surrounding the Nigerian educational sector. The more educated Nigerians are, the more financially included they will be. Special attention should also be given to educating the female section of the Nigerian 
populace. This would ensure that there is a balance when forming better educational frameworks in the future.

\section{References}

[1] Ajide, K. B. (2014). Determinants of foreign direct investment in ECOWAS. The Empirical Econometrics and Quantitative Economics Letters, 3(2), 51-74.

[2] Beck, T., Behr, P., \& Madestam, A. (2011). Sex and credit: Is there a gender bias in lending? European Banking Center Discussion Paper, (2011-027).

[3] Presbitero, A. F., Rabellotti, R., and Piras, C. (2014). Barking up the Wrong Tree? Measuring Gender Gaps in Firm's Access to Finance. The Journal of Development Studies, 50(10):1430-1444.

[4] Henderson, L., Herring, C., Horton, H. D., \& Thomas, M. (2015). Credit Where Credit is Due? Race, Gender, and Discrimination in the Credit Scores of Business Startups. The Review of Black Political Economy, 42(4):459-479.

[5] Karlan, D., and Zinman, J. (2010). Expanding credit access: using randomised supply decisions to estimate the impacts. Review of Financial Studies, 23(1): 433464.

[6] Demirguc-kunt, A., and Klapper, L. (2013). Measruring financial inclusion: explaining variation in use of financial services across and within countries. Brookings Papers on Economic Activity, Spring 2013, 279340.

[7] Dupas, P., and Robinson, J. (2013). Savings Constraints and Microenterprise Development: Evidence from a Field Experiment in Kenya. American Economic Journal: Applied Economics 5(1), 163-192.

[8] Karpowicz, I. (2014). Financial Inclusion, Gowth and Inequality: A Model Application to Colombia. Washington, DC: International Monetary Fund.

[9] Chiapa, C., Prina, S., \& Parker, A. (2016). The effects of financial inclusion on children's schooling, and parental aspirations and expectations. Journal of International Development, 28:683-696. https://doi. org $/ 10.1002 / \mathrm{jid}$.

[10] Duflo, E. (2009). Women empowerment and economic development. Journal of Economic Literature, 50(4), 1051-1079. https://doi.org/10.1257/ jel.50.4.1051.

[11] Prina, S. (2013). Banking the poor via saving accounts : Evidence from a field experment. Journal of Development Economics, 115:16-31.

[12] Demirguc-Kunt, A., Klapper, L., Singer, D., and P. V. Ouheusden (2015). The global findex database 2014: Measuring financial inclusion around the world. Policy Research Working paper 7255. World Bank
Group.

[13] World Bank. (2012). Women, business and the law: Removing barriers to economic inclusion - Measuring gender parity in 141 economies. Washington, DC: The International Bank for Reconstruction and Development/The World Bank. Retrieved from http:// wbl.worldbank.org/reports.

[14] Aduda, J., and E. Kalunda (2012). Financial inclusion and financial sector stability with reference to Kenya: A review of literature .Journal of Applied Finance and Banking, 2 (6), 95-120. ISSN: 1792-6580 (print version), 1792-6599 (online).

[15] Arora, R. (2010). "Measuring Financial Access". Griffith University, Discussion Paper Economics 7, ISSN1837-7750.

[16] Gupte, R. , Venkataramani, B. , \& Gupta, D. (2012). "Computation of financial inclusion index for India". International Journal of Procedia - Social and Behavioral Sciences, 37, 133 - 149.

[17] Nandru, P. , Anand, B. , \& Rentala, S. (2015). Factors influencing financial inclusion through banking services. Journal of Contemporary Research in Management, 10(4): 17-30.

[18] Allen, F. Demirgüç-Kunt, A., Klapper, L. and Martinez Peria, M. S. (2012). "The Foundations of FI. Understanding Ownership and Use of Formal Accounts". The World Bank. Development Research Group. Finance and Private Sector Development Team. Policy Research Working Paper 6290, World Bank, Washington, DC.

[19] Kholi, N. (2013). "Financial Inclusion \& its Impact on Banking Sector in India". Tecnia Journal of Management Studies, 7(2).

[20] Efobi, U., Beecroft, I \& Osabuohien, E (2014). "Access to and use of bank services in Nigeria: Micro-econometric evidence". Review of development finance, 4, 104-114.

[21] Jann, B(2008). The Blinder-Oaxaca decomposition for linear regression models. The Stata Journal 8(4):453-479.

[22] Oaxaca, R. L., 2007. The challenge of measuring labor market discrimination against women. Swedish Economic Policy Review. 14(1):199.

[23] Pindyck, S. R., \& Rubinfeld, L. D. (1998). Econometric Models and Economic Forecasts 4th Edition. New York: McGraw-Hill.

[24] Greene, W. H. (2008). Econometric Analysis. 6th ed. Upper Saddle River, NJ: Prentice Hall.

[25] Alliance for Financial Inclusion (AFI) as contained in the Policy Frameworks to Support Women's Finan- 
cial Inclusion (March, 2016 report).

[26] Karlan, D. and J. Morduch. 2009. "Access to Finance." In Handbook of Development Economics, vol. 5, edited by D. Rodrik and M. Rosenzweig,
4703-84. Elsevier.

[27] Global Findex Database 2014: measuring financial inclusion around the world. World Bank Policy Research Working Paper, (7255). 